\title{
Kathman and Martin share plans for ACRL
}

\author{
By Michael D. Kathman and Susan K. Martin
}

\section{ACRL's 1993 presidential candidates'statements}

E d. note: CERL News offered ACRL candidates for vice-president/president-elect, Michael D. Kathman and Susan K. Martin, this opportunity to share their views with the ACRL membership. Although many of the issues and concerns facing ACRL are discussed informally at meetings, this does not provide a national forum available to all members. We hope that providing this forum will assist you in making an informed choice when you receive your ballot from ALA next month.

\section{MICHAEL D. KATHMAN}

As the needs and circumstances of academic librarians, libraries, and library users change, so must the association that represents them. Rapid technological advancement, which is changing all of our lives, is occurring at a time when resources are extremely tight for the institutions we serve and for ACRL. Just as we recognize that our own libraries cannot continue to do all we have done in the past and provide all of the new services now available and important to our patrons, ACRL needs to prioritize within these same limitations. In order to meet the needs of 21st-century libraries and librarians, the association may have to curtail some of the services it has been providing in favor of these new services.

Just as we have to consider both "haves" and "have nots" in our own institutions-those with computers and those without, those who can afford the value-added services some of us charge for and those who cannot-the same is

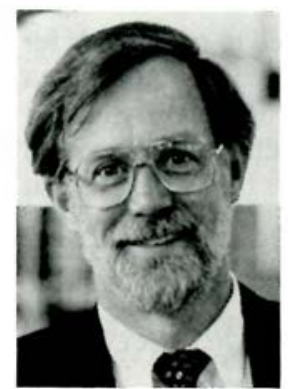

Michael D. Kathman

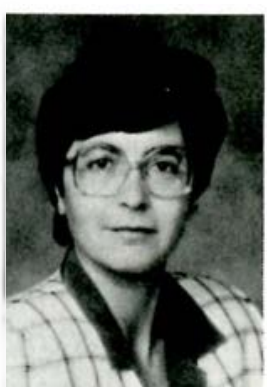

Susan K. Martin true for ACRL. Some members have access to the Internet and some do not, some can afford to attend Midwinter, Annual, and ACRL National Conferences and some cannot. We must enhance our service delivery systems so that members who cannot afford out-of-state conferences can benefit in other ways through the association. Our publications, lobbying efforts, promulgation of standards, and support of chapters may need adjustment to take advantage of the technologies now available. Additional and more cost-effective ways need to be found to meet the current and future needs of our members.

\section{Background}

My membership in ACRL began in the early 1970 s, first with active participation in the Community and Junior College Libraries Section and later in the College Libraries Section. I have served on numerous ACRL committees including handling of the contributed papers for the Second ACRL Conference and chairing the Strategic Planning Committee. I have served on many ACRL task forces such as the Task Force on Library and Computer Centers, the Task Force on Implementing a Revised Operating 
Agreement, and the Task Force on Publications, which I currently chair. I also chaired the College Libraries Section in 1990-91. Other activities included six years on OCLC's User Group, with two of those years on the executive committee, and many years of service to our regional network in a variety of capacities. I also served as president of the Minnesota Library Association. These activities have broadened my understanding of the issues facing ACRL and the library profession.

\section{Issues}

Unit leaders have responded to my request for identification of the issues facing ACRL with some fervor. Direct communication with the units is the way in which the association achieves its Strategic Plan. I firmly believe that

\section{My major goal is to belp librarians and libraries meet}

\section{the needs of current and}

future users.

the strength of the association is in its unitssections, committees, and chapters; through them the needs of individual librarians can best be identified and met. But the association's lack of resources for the many agenda items it wishes to accomplish results in the units receiving a smaller and smaller share of the revenues. The items most important to the units-section newsletters and funding for programs-are being cut and/or reviewed for possible cuts.

Issues that need to be addressed are many; I will highlight just a few:

1) The Strategic Plan needs to be thoroughly revised. The time has come to look more toward the future. The current plan has aged well, but in a time of tight resources the plan needs to be less all-encompassing and more targeted. The plan is the document the Board must use to allocate the association's resources.

2) The units have taken the brunt of the budget cutting. This, I believe, is due to the Board's lack of time (the cuts had to be made very quickly) to do a thorough review of all of the association's activities. That review, if not already underway, needs to be done.

3) Much of the discussion of both the current issues and the future of academic librarianship is occurring outside ACRL, primarily on list servers. This discussion has to be brought back to the ACRL planning process. Hopefully, more of that discussion can occur within ACRL.

4) The sections have a need to communicate directly with their membership. This need is currently being met by the newsletters, but they are costly and sometimes heavily subsidized by the membership of the section. For some of the subject-oriented sections, the newsletters are the major source of information about issues that have a limited audience and might not be published if the newsletters did not exist. This communication must continue although it might be packaged differently.

5) Some librarians feel left out of ACRL either because of the type of library they represent or because they and their institutions cannot afford to send them to major conferences. This necessitates a continuing and growing role for chapters. We need to look at regional or electronic ways to deliver services to members. The Science and Technology Section's experiment with an electronic newsletter and the Community and Junior College Libraries Section's successful teleconferences may be examples of future ways to meet members' needs.

6) The relationship between ACRL and ALA has been discussed for many years. The operating agreement has strained the relationship due to its financial implications. This strained relationship may continue for the foreseeable future but I believe we need to work on it; we must not forget that there is great value in that relationship. Librarians speaking together are much more effective than speaking separately,

7) ACRL, like all large organizations, has many policies and procedures, each of which was formulated for a reason; periodically it is necessary to review policies and procedures to make certain they are still necessary. During my years as chair of the Strategic Planning Committee I attempted to reduce the paperwork while still achieving the goals of the committee. I will do the same for all of ACRL if elected.

\section{Goals}

My major goal is to help librarians and libraries meet the needs of current and future users. We need to address the issues identified above and as stated in the existing Strategic Plan; the association needs: "To sponsor and encourage opportunities for academic and research librarians to update existing competencies, learn requisite new skills, and gain awareness of the state of the art." 
In a recent article about the knowledge society we live in, Peter Drucker stated, ". . . it is safe to assume that anyone with any knowledge will have to acquire new knowledge every four or five years or become obsolete." Practically, we need to move beyond the way information has traditionally come to us-in one type of packaging with a table of contents at the beginning, an index at the end, the information accessible on a random basis, and a consistent user interface. The interface was highly portable and even worked when the power was out. We now have large packages of information that have inconsistent user interfaces and, just as we begin to master one new interface, two more become available.

We are only beginning to use the Internet as an information resource. Learning to use the Dialog databases will be considered easy, I believe, compared to what it will take to learn how to use the Internet effectively. What is currently being done to assist librarians to upgrade their skills in this area? How will we learn what we need to know and what role will ACRL play? These are important questions and I believe the answers will have to come out of ACRL within the next three years. Responding to these questions will not be easy. The financial constraints of the association only compound the problem.

\section{Conclusion}

Changing the direction of a professional association is like changing the direction of a large ocean liner; it can be done, but slowly. Current ACRL leaders are involved in the process of changing direction, but the process must continue with diligent attention and expert guidance. I believe that my experience serving ACRL puts me in a position to understand the complexities of these issues. My knowledge of the structures and of the membership are basic to my belief that the association under my leadership can meet the challenges librarians and libraries will be facing for the next ten years and beyond.

\section{Nores}

'Peter Drucker, "The New Society of Organizations," Harvard Business Review (SeptemberOctober 1992): 96.

\section{SUSAN K. MARTIN}

ACRL is a strong and active organization whose membership has grown considerably in the past decade, and whose influence is being enhanced by virtue of the establishment of 41 chapters in states and regions. It provides a healthy forum for academic librarians, and simultaneously faces issues and decisions which will be critical for its own future, as well as for the future of academic librarianship.

\section{A vision for the profession}

The discussion that has taken place in the past 18 months regarding the strategic vision that librarians should develop for themselves is pivotal for ACRL and its membership. We are all concerned that we may not be attracting the "best and the brightest" into the profession; we recognize that librarianship, which once was in the lead in information technology, has lost that lead not only to other professions but sometimes even to individual consumers and users. The economic situations that affect our institutions negatively have a tendency to dampen the creativity and spirit that librarians should bring to the information arena. ACRL has already recognized these issues. One of the best-

\section{We will have to prove the worth of the library, and of ourselves as} librarians, within this new world.

attended meetings at the National Conference last year was the one on strategic visions. We need to take several additional steps. ACRL must encourage chapters to address the question of the visions and values of librarianship at the local and regional level, and its members must stand up as leaders in the application of information in the service of our society.

Also, the entire question of the survival of library schools and library education is one in which ACRL needs to be seriously concerned.

The visibility of academic librarianship is closely allied to the strategic vision, the education of professionals, and the development of libraries to serve the future needs of our academic communities. We know that the funding of academic institutions must change; it is also a distinct possibility that the university as we know it will have to change in the coming years in response to economic and societal pressures. As academic librarians, we can no longer mouth the phrase that "the library is the heart of the university." We will have to prove the 
worth of the library, and of ourselves as librarians, within this new world. ACRL can and will support us in helping our universities shape their future.

\section{ACRL and its chapters}

The ACRL chapter structure allows the participation of librarians throughout the nation to take an active role in the association even if they are unable to attend ALA meetings or ACRL national conferences. This structure has grown so rapidly in the past few years that some attention must be paid to the relationship of the national organization to the chapters, and more particularly to the ACRL focus, priorities, and strategic plan as they relate to the chapters.

Working with ACRL members and leaders at both the national and local levels, I would encourage the identification of issues (such as strategic visions for librarians) that should be addressed in both arenas, and where such conversation could be brought together to create a real and positive difference for academic librarians.

\section{ACRL and ALA}

Planning and priorities have been the key words for several years, and ACRL has done a remarkable job of identifying its direction. Working within the evolving operating agreement with ALA, there are still many questions to be sorted out. I anticipate that in the coming two or three years it will be necessary for ACRL members to make choices about which programs they wish to support. The past experience of being able to accomplish every goal and objective desired by the membership may no longer be a reality; I expect to work closely with members, sections, discussion groups, and chapters to achieve agreement on priorities to support.

\section{In conclusion}

I am honored to be a candidate for the position of vice-president/president-elect of an organization that has been very important to the success of academic librarianship in the past and promises to be critical to its survival in the future. In addition to being a member of ACRL and active for the past 25 years, I have been a president of another division (LITA) as well as an ALA councilor. The concerns and impacts of division-level issues would provide me and ACRL members with the opportunity to make significant and positive changes in the way we do business both in our libraries and in our professional organizations. I welcome that opportunity!

The English Poetry Full-Text Database

provides complete electronic access to

the works of 1,350 poets from the Anglo-Saxon period to the end of the

19th century.

Scholars can now access the complete

text of 4,500 volumes of English poetry

from a personal computer.

For more information or to request

a free demonstration diskette, call

Chadwyck-Healey toll-free at

800-752-0515. 